\title{
INFLUENCE OF MICROCLIMATIC CONDITIONS ON THE DAILY PRODUCTION OF DAIRY COWS
}

\author{
D. Kučević ${ }^{1}$, M. Plavšić ${ }^{1}$, S. Trivunović ${ }^{1}$, M. Radinović $^{1}$, V. Bogdanović ${ }^{2}$ \\ ${ }^{1}$ Faculty of Agriculture, Department of Animal Science, Novi Sad, 21000 \\ ${ }^{2}$ Faculty of Agriculture, Zootechnical Institute, Belgrade - Zemun, 11080 \\ Corresponding author: \\ Denis Kučević; e-mail: denis.kucevic@stocarstvo.edu.rs \\ Original scientific paper
}

Abstract: The aim of this paper was to determine the microclimatic conditions (ambient temperature and relative humidity) in dairy farm, as well as to evaluate the effect and significance of temperature - humidity index (THI) values on the daily milk yield. The observation of microclimatic parameters was conducted in the period from 9.03.2012 to 6.05.2012. The study included 136 Holstein Friesian cows. The estimation of the effect of THI on daily production of dairy cows was defined by applying fixed-effect statistical model. Average ambient temperature during measuring months amounted to $15.6^{\circ} \mathrm{C}$ (ranging from $7.2^{\circ} \mathrm{C}$ to $24.6^{\circ} \mathrm{C}$ ), while the average value of relative humidity was $56.33 \%$ (ranging from $40.30 \%$ to $81.80 \%$ ). During the study, the mean value of THI was 58.93 (ranging from 47.08 to 70.13) and didn't exceed the critical comfort level of 72. All tested fixed-factors were statistically affected the daily milk yield $(p<0.01)$. For each unit of increase in the value of the THI, the amount of milk decreased by $0.05344 \mathrm{~kg}$. This confirmed the importance of regular recording of THI values and microclimatic conditions as a unique indicator of thermal stress in dairy farm.

Key words: temperature - humidity index, dairy cows, milk yield, microclimatic parameters, heat stress

\section{Introduction}

Heat stress can have a very negative impact on milk production, reproduction and general health of cows (Kadzere et al., 2002; West, 2003; Hansen, 2007). In regard to heat stress, the most important factors are classified as ambient temperature and relative humidity (Ravagnolo and Misztral, 2000; Bouraoui et al., 2002; Correa - Calderon et al., 2004). Highly yielding dairy cattle in lactation show the most sensitivity to heat stress (Cincović, 2010). Influence of negative climatic factors may cause a decrease in milk production of lactating cows from $3 \%$ to $10 \%$ (Hristov et al., 2007). Acording to West (2003), when the 
ambiental temperature is $35^{\circ} \mathrm{C}$, milk production decreases by $33 \%$, and when the temperature is $40^{\circ} \mathrm{C}$, milk production reduces to $50 \%$. Thermoregulatory capabilities of cattle mostly depend on the ambient relative humidity level and temperature. Based on that, a unique indicator for environmental thermal stress was created, the temperature humidity index (THI) (Mc Dowel et al., 1976).

THI is the most common and most accurate mean of temperature stress assessment (Akyuz et al., 2010) and will be used to determine the influence of heat stress on productivity of dairy cows. Milk production is affected by heat stress when THI values are higher than 72 , which corresponds to $22^{\circ} \mathrm{C}$ at $100 \%$ humidity, $25{ }^{\circ} \mathrm{C}$ at $50 \%$ humidity, or $28{ }^{\circ} \mathrm{C}$ at $20 \%$ humidity (Du Preez et al., 1990a).

\section{Materials and Methods}

The research was conducted from March 9th 2012 to May 6th 2012, on a dairy farm in Čantavir, Serbia. Cows were reared in a free system, capacity of 160 cattle in a single stable. The research included 136 Holstein cows. The facility used for the housing was divided into 5 departments with cow cubicles. The cows were grouped according to the lactation stadium. The horizontal ventilation was provided in the barn, whereas on the sides, curtains were added for additional micro climate regulation.

The amount of milk produced per cow, was measured by automated devices in the milking parlor. Temperature and humidity were measured every hour, during the experiment. Measurements were taken with three "data loggers" (Humidity and Temperature test $174 \mathrm{H}$ logger). The equipment was positioned in level with the cows withers, attached to the columns in each facility. The daily THI values were calculated using the equation by Kibler (1964):

THI $=1,8$ Ta-(1-RH)(Ta-14,3)+32

where:

THI - temperature humidity index

$\mathrm{Ta}$ - temperature detected in stable

$\mathrm{RH}$ - relative humidity

Data was analysed using the software Statistics 10 (stat. Soft. Inc. 2012). General variability of observed traits was analysed using the descriptive statistical analysis and the connection between the milk production and THI by the model of linear regression. Different sources of variability on daily milk yield were defined by applying the following statistical model:

$\mathrm{Y}_{\mathrm{ijk}}=\mu+\mathrm{L}_{\mathrm{i}}+\mathrm{S}_{\mathrm{j}}+\mathrm{b}_{1}\left(\mathrm{x}_{1}-\bar{x}_{1}\right)+\mathrm{b}_{2}\left(\mathrm{x}_{2}-\bar{x}_{2}\right)+\mathrm{b}_{3}\left(\mathrm{x}_{3}-\bar{x}_{3}\right)+\mathrm{e}_{\mathrm{ijk}}$

$\mathrm{Y}_{\mathrm{ijk}}$ - phenotypic value of observed traits 
$\mu$ - population average

$\mathrm{L}_{\mathrm{i}}-$ fixed effect of the parity

$\mathrm{S}_{\mathrm{j}}$ - fixed effect of the calving season

$\mathrm{b}_{1}\left(\mathrm{x}_{1}-\bar{x}_{1}\right)$ - linear regression effect of the age by calving

$\mathrm{b}_{2}\left(\mathrm{x}_{2}-\bar{x}_{2}\right)$ - linear regression effect of the THI index

$\mathrm{b}_{3}\left(\mathrm{x}_{3}-\bar{x}_{3}\right)$ - linear regression effect of the stage of lactation

$\mathrm{e}_{\mathrm{ijk}}$ - other uncontrollable effects (random error)

\section{Results and Discussion}

Variations in the ambient temperature $\left(\mathrm{Ta},{ }^{0} \mathrm{C}\right)$, relative humidity $(\mathrm{RH}, \%)$, and the THI in the stable recorded during the measuring months are reported in Table 1 .

Table 1. Average values of microclimate conditions, THI and milk yield during measuring months ${ }^{1}$

\begin{tabular}{|l|c|c|c|c|c|c|c|}
\hline Parameters & $\mathrm{n}$ & $\mathrm{X}$ & $\mathrm{SD}$ & $\mathrm{CV}$ & $\mathrm{Se}$ & $\min$ & $\max$ \\
\hline Average milk yield & 7746 & 24.62 & 7.48 & 30.40 & 0.09 & 1.60 & 49.50 \\
\hline $\mathrm{Ta},{ }^{\circ} \mathrm{C}$ & 4173 & 15.63 & 4.42 & 28.26 & 0.58 & 7.20 & 24.60 \\
\hline $\mathrm{RH}, \%$ & 4173 & 56.33 & 11.45 & 20.33 & 1.49 & 40.30 & 81.80 \\
\hline THI & 4173 & 58.93 & 5.75 & 9.76 & 0.75 & 47.08 & 70.13 \\
\hline
\end{tabular}

${ }^{1} \mathrm{Ta}$ - ambient temperature $\left({ }^{\circ} \mathrm{C}\right)$; $\mathrm{RH}$ - relative humidity (\%); THI - temperature-humidity index

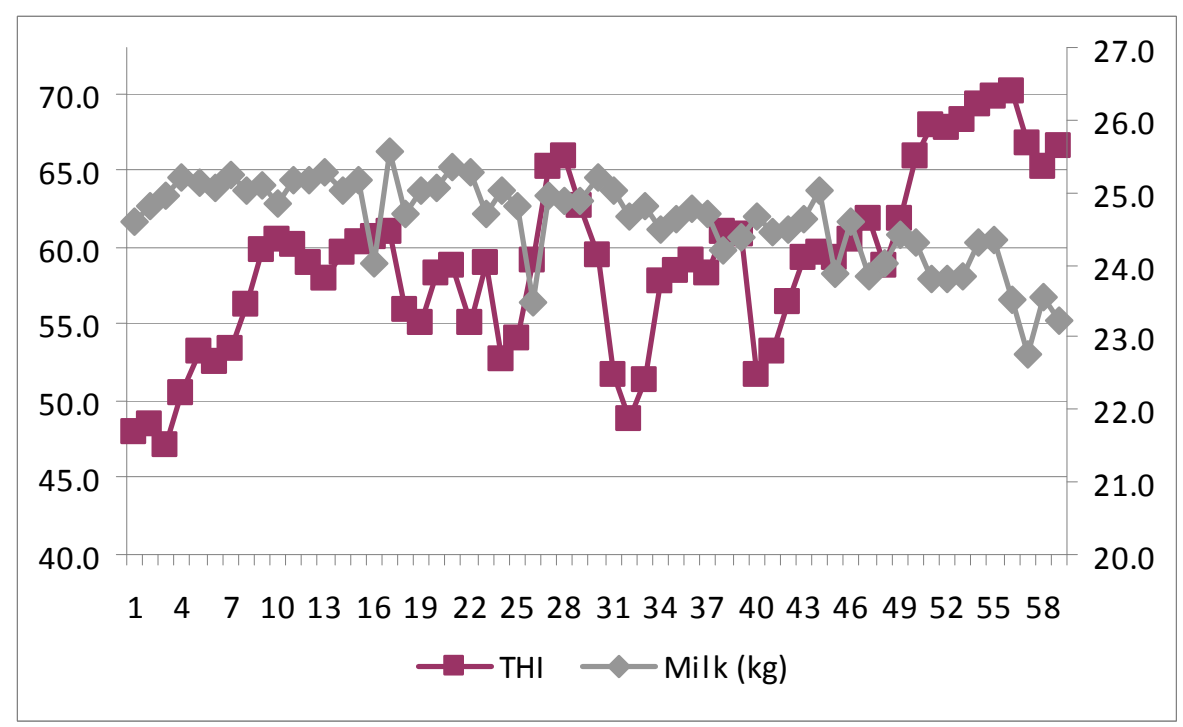

Figure1. Average temperature-humidity index and daily milk yield per cow during the period of observation 
According to Table 1, average ambient temperature during measuring months amounted to $15.6^{\circ} \mathrm{C}$ (ranging from $7.2^{\circ} \mathrm{C}$ to $24.6^{\circ} \mathrm{C}$ ), while the average value of relative humidity was $56.33 \%$ (ranging from $40.30 \%$ to $81.80 \%$ ). During the study the mean value of THI was 58.93 (ranging from 47.08 to 70.13) and didn't exceed the critical comfort level of 72 (Figure 1). Optimal ambient temperature for dairy cows is $10^{\circ} \mathrm{C}$ to $15^{\circ} \mathrm{C}$ and comfort zone range from $5^{\circ} \mathrm{C}$ to $21^{\circ} \mathrm{C}$ (Čobić and Antov, 1996). Kic and Brož (1995) noticed that the optimal value of relative humidity ranges from $50 \%$ to $70 \%$ for lactating cows.

By temperatures higher than $26^{\circ} \mathrm{C}$, cows reach a point where they are not able to cool themselves adequately, respectively to maintain constant body temperature and they enter the stage of temperature stress (Kadzere et al., 2002). The same authors find that THI values of 70 and less are comfortable, from 75 to 78 stressful, and values above 78 cause extreme danger, preventing the cows to maintain their normal body temperature.

Bouraoui et al. (2002) reported that if the THI value is between 35 and 72 , the conditions for temperature stress occurrence are not met, and there are no conditions for the reduction of milk yield. Akyuz et al. (2010) noticed that the mild stress is experienced just when the value passes critical 72 , moderate stress at 79 and at the end the dangerous level with values higher than 89 .

Effects of THI and other observed factors (age by calving, stage of lactation, parity and calving season) on daily milk yield are shown in table 2 .

Table 2. Effect of observed factors on daily milk yield ${ }^{\mathbf{1}}$

\begin{tabular}{|l|c|c|c|c|}
\hline Source of variability & d.f. & MS & F & $\mathrm{p}$ \\
\hline Age at calving & 9 & 2543.6 & 89.998 & $0.000000^{* *}$ \\
\hline THI & 1 & 746.6 & 26.417 & $0.000000^{* *}$ \\
\hline Stage of lactation & 1 & 182096.2 & 6443.043 & $0.000000^{* *}$ \\
\hline Parity & 1 & 2597.1 & 91.893 & $0.000000^{* *}$ \\
\hline Calving season & 1 & 1508.4 & 53.373 & $0.000000^{* *}$ \\
\hline
\end{tabular}

$1 \mathrm{~d}$.f. $=$ degrees of freedom; $\mathrm{MS}=$ mean square; $\mathrm{F}=\mathrm{f}$ - value;

$\mathrm{NS}=\mathrm{P}>0.05 ; *=\mathrm{P}<0.05 ; * *=\mathrm{P}<0.01 ; * * *=\mathrm{P}<0.001$;

The effects of the THI, age at calving, stage of lactation, parity and calving season were very highly significant $(\mathrm{p}<0.0001)$ for daily milk yield. table 3 .

Coefficient of linear regression of the THI index on milk yield is shown in 
Table 3. Value of the coefficient of linear regression ${ }^{1}$

\begin{tabular}{|l|l|l|l|l|}
\hline & $\mathrm{b}$ & Std. error $\mathrm{b}$ & $\mathrm{t}$ - value & $\mathrm{P}-$ value \\
\hline $\mathrm{a}$ & 27.75637 & 0.871253 & 31.85797 & $0.000000^{* *}$ \\
\hline THI & -0.05344 & 0.014642 & -3.65001 & $0.000264^{* *}$ \\
\hline
\end{tabular}

Coefficient of linear regression of the THI index on milk yield was negative -0.05344 , which means that for each THI unit increase, milk yield decreases by $0.05344 \mathrm{~kg}$.

Effect of THI on daily milk yield was also observed in other studies. Cincović and Belić (2009) have reported that, when THI reaches 72, a daily milk yield per cow decline by $0.2 \mathrm{~kg}$. West (2003) stated that the daily milk yield per cow of Holstein breed decrease in average by $0.88 \mathrm{~kg}$, per each unit of increase in THI. According to Gantner et al. (2011) the highest amount of daily loss ( $>0.9$ $\mathrm{kg} /$ day) was determined in heifers.

Study of Zimbelman et al. (2009) has shown that the daily milk yield decreased around $2.2 \mathrm{~kg}$ /day by THI values from 65 to 73 . Bouraoui et al. (2002) showed that when the THI index increases from 68 to 78, the decline of milk yield production totals $4 \mathrm{~kg}$, and for each THI unit increase, above 69 , daily milk yield per cow reduces for another $0.41 \mathrm{~kg}$. Ravagnolo (2000) determined that milk yield declined by $0.2 \mathrm{~kg}$ per unit increase in THI when THI exceeded 72. Falta et al., (2008) have also found that for THI values above 72, a milk yield decline of $4 \mathrm{~kg}$ occurs.

\section{Conclusion}

Based on the research of microclimate conditions (ambient temperature and relative humidity) as well as the effect of temperature-humidity index values on the daily production of dairy cattle, it could be emphasized that there were no conditions for the occurrence of heat stress during the experiment period because THI didn't exceed the critical comfort level of 72. The effects of the THI and other observed factors were very highly significant $(p<0.0001)$ for daily milk yield. Amount of decrease of daily milk yield was not as high as in the results of other the authors, probably because the experiment was conducted in the spring when the critical limit of 72 is rarely exceeded. It has confirmed the importance of regular recording and monitoring of THI values and microclimatic conditions as a unique indicators of thermal stress on dairy farm, especially during the summer months when ambient temperature is around $40^{\circ} \mathrm{C}$. Except monitoring of THI values, it is necessary to regulate the dairy management with the aim to minimize the effects of heat stress. 


\title{
Uticaj mikroklimatskih uslova na dnevnu proizvodnju mleka krava
}

\author{
D. Kučević, M. Plavšić, S. Trivunović, M. Radinović, V. Bogdanović
}

\section{Rezime}

Cilj ovog rada je bio da se utvrde mikroklimatski uslovi (ambijentalna temperatura i relativna vlažnosti vazduha) $\mathrm{i}$ ispita uticaj različitih vrednosti temperaturno - humidnog indeksa (THI) na dnevnu proizvodnju mleka muznih krava. Period posmatranja mikroklimatskih parametara je sproveden u vremenu od 9.03.2012 do 6.05.2012. Ispitivanje je obuhvatilo 136 grla holštajn frizijske rase krava. Za procenu uticaja THI na dnevnu proizvodnju mleka korišten je statistički model sa uticajima fiksnih faktora. Prosečna temperatura ambijenta u toku ogleda je iznosila $15,6^{\circ} \mathrm{C}$ (kretala se od $7,2^{\circ} \mathrm{C}$ do $24,6^{\circ} \mathrm{C}$ ) dok je prosečna relativna vlažnost vazduha iznosila $56,33 \%$ (kretala se od $40,30 \%$ to $81,80 \%$ ). Za vreme istraživanja prosečna vrednost THI je iznosila 58,93 (kretala se od 47,08 do 70,13) i nije prelazila kritičan nivo komfora od 72 . Svi ispitivani fiksni faktori su statistički značajno uticali na prinos mleka $(\mathrm{p}<0,01)$. Za svaku jedinicu porasta vrednosti THI, količina mleka se smanjivala za $0,05344 \mathrm{~kg}$. Potvrđena je važnost redovnog praćenja THI i mikroklimatskih uslova kao jedinstvenog pokazatelja termalne stresogenosti sredine u kojoj borave krave muzare.

\section{References}

AKYUZ, A., BOYACI, S., CAYLI, A. (2010): Determination of critical period for dairy cows using temperature humidity index, Journal of Animal and Veterinary Advances, 9 (13), 1824 - 1827.

BOURAOUI R., LAHMAR M., MAJDOUB M., DJEMALI, M., BELYEA, R. (2002): The relationship of temperature - humidity index with milk production of dairy cows in a Mediterranean climate, Anim. Res. 51, $479-491$.

CINCOVIĆ M. R. (2010): Toplotni stres krava - fiziologija i patofiziologija, Monografija, zadužbina Andrejević, Beograd,

CINCOVIĆ, M. R., BELIĆ B. (2009): Uticaj termalnog stresa krava na količinu i kvalitet proizvedenog mleka, Veterinarski žurnal Republike Srpske, vol. IX, broj 1, 53-56.

ČOBIĆ T., ANTOV G. (1996): Govedarstvo - prozvodnja mleka, S print, Novi Sad.

CORREA - CALDERON, A., ARMSTRONG D., RAY, D., DENISE S., ENNS M., HOWISON C. (2004): Thermoregulatory response of Holstein and Brown 
Swiss heat - stressed dairy cows to two different cooling systems, Int. J. Biometeorol. 48, 142 - 148.

DU PREEZ J.H., GIESECKE W.H., HATTINGH P.J. (1990a): Heat stress in dairy cattle and other livestock under Southern African conditions. I. Temperaturehumidity index mean values during the four main seasons. Onderstepoort J. Vet. Res. 57, 77-86.

FALTA D., WALTEROVA L., SKYPALA M., GHLADEK G. (2008): Effect of stable microclimate on milk production of Holstein cows on the 2 nd and 3 rd lactation, AWETH, vol 4. issue 2, 104-110.

GANTNER V., MIJIĆ P., KREŠIMIR KUTEROVAC, K., DRAGO, D., GANTNER R.: (2011) Temperature-humidity index values and their significance on the daily production of dairy cattle. Mljekarstvo 61 (1), 56-63.

HANSEN P. J. (2007): Exploitation of genetic and physiological determinants of embrionic resistance to elevated temperature to improve embryonic survival in dairy cattle during heat stress, Theriogenology, 68, S242 - S249.

HRISTOV S., STANKOVIĆ B., JOKSIMOVIĆ - TODOROVIĆ M., BOJKOVSKI J., DAVIDOVIĆ V. (2007): Uticaj toplotnog stresa na proizvodnju mlečnih krava, Zbornik naučnih radova, vol. 13, br. 3-4, 47 - 54 .

KADZERE C. T., MURPHY M. R., SILANIKOVE N., MALTZ E. (2002): Heat stress in lactating dairy cows: a review, Livestock Production Science 77, 59-91.

KIBLER H. H. (1964): Environmental physiology and shelter engineering, LXVII, Thermal effect of various temperature - humidity combinations on Holstein cattle as measured by eight physiological response, Res. Bull. Missouri. Agric. Exp. Station., 862.

KIC P. A BROŽ V. (1995): Tvorba stajoveho prostředi, 1. vyd. Praha: Institut vychovy a vzdělavani Ministerstva zemědělstvi Česke republiky, 47 s. ISBN 807105-106-3.

MCDOWEL R. E., HOOVEN N. W., CAMOENS J. K. (1976): Effect of climate on performance of Holsteins in first lactation, J. Dairy Sci., 59, 965 - 973.

RAVAGNOLO O., MISZTRAL I. (2000): Genetic component of heat stress in dairy cattle, parameter estimation, J. Dairy Sci. 83, 2126 - 2130.

WEST, J. W. (2003): Effect of heat stress on production in dairy cattle. Journal of Dairy Science, 86: 2131-2144.

ZIMBELMAN R. B., RHOADS R. P., RHOADS M. L., DUFF G. C., BAUMGARD L. H., COLLIER R. J. (2009): A Re-evaluation of the impact of temperature humidity index (THI) and black globe humidity index (BGHI) on milk production in high producing dairy cows, Proc. 24th Ann. SW Nutr. Mgmt. Conf., $158-158$. 